\title{
Let's All Recruit!
}

$I^{\mathrm{N}}$ N HIS RECENT ARTICLE, "College Librarians and Recruiting,"1 John F. Harvey, chairman of the Joint Committee on Library Work as a Career, says that "everyone talks about the personnel shortage, but few librarians do anything about it." Let me go one step farther and draw attention to the fact that we college and university library staff members, as a whole, are doing far less than any other group although, in general, we occupy positions which offer the greatest potentialities for recruiting.

Surely all college and university librarians are only too well aware of the seriousness of the personnel shortage. It be- hooves us to stop merely talking and begin doing. As chairman of your Committee on Recruiting, I urge and exhort every one of you ACRL members to carry on an active, continuing campaign to bring desirable recruits into the profession.

The following checklist of suggestions for recruiting has been compiled as a guide for you. However, it is well for you to bear in mind that associations and committees can help only by providing stimulation and information and by furnishing recruiting materials. In the last analysis, all recruiting is on an individual, personal basis. So, let's all recruit!

\section{CHECKLIST OF SUGGESTIONS FOR RECRUITING}

\section{On the National Level}

Stimulating state library associations and other groups to inaugurate recruiting programs or to intensify those already in operation

Providing a clearing house for the exchange of information regarding current recruiting activities

Preparing posters, booklets, leaflets, exhibits, etc. for national distribution

Encouraging the preparation of articles on recruiting in national professional journals and in popular nonprofessional magazines

Keeping librarians informed with regard to opportunities in the field, and keeping in close contact with the library schools

Publicizing information about scholarships, graduate and undergraduate

Seeking scholarship grants from industries, professions, and others for training librarians in their fields

${ }^{1}$ CRL, XVI (1955), 368.69.

Dr. Watson is librarian, Northwestern State College of Louisiana, Natchitoches.
Establishing loan funds

Giving prizes for the best biographies and fiction about librarians

Publishing a practical manual on recruiting techniques

\section{On the State Level}

Originating programs of recruiting activities

Stimulating individuals and local groups to conduct active recruiting campaigns

Coordinating, as far as possible, all recruiting activities in the state

Preparing recruiting leaflets for state-wide distribution

Promoting recruiting activities in college, high school, and public libraries

Developing a broad program of publicity on librarianship as a career, directed toward: (1) elementary school pupils, (2) high school pupils, (3) college students, (4) vocational counselors, (5) parents, (6) teachers, (7) school administrators, (8) employment agencies

Conducting recruiting sessions at conventions of state library associations

Entertaining prospective librarians at conventions of state library associations 
Sending newsletters to college students who are interested in librarianship as a career

Establishing loan funds and encouraging the giving of scholarships

Sponsoring a "library week" during which boys and girls are invited to visit college and public libraries and learn about the types of work that are done in them

Establishing speakers' bureaus

Maintaining booths with recruiting materials at various group meetings and conventions

On the Local and Individual Level

Displaying enthusiasm for and satisfaction and belief in librarianship

Taking part in community interests and activities; being alert and dynamic; and rendering community service

Giving courteous, friendly, intelligent service in every library; giving the type of service people want

Keeping libraries attractive and inviting

Presenting librarianship-the philosophy of library service-to prospects in a worthwhile and attractive light

Showing prospects the abundant personal and social rewards of librarianship

Convincing parents and children that librarians make a good social contribution

Having dinners or teas for librarians, teachers, high school students, and other young people who are interested in librarianship (have fun, but give them information about the profession)

Participating in high school "career days" and "vocation days"

Setting a good example to library clerks and pages, and following up the interest revealed by likely prospects or stirring up that interest where it may already be latent

In the Library Schools

Putting 18 semester hours of library science on the undergraduate level, and including subject-field electives in graduate work
Adding vitality and attractiveness to educational programs

Making the instruction more realistic; using practicing librarians in the training programs

Recognizing and training for special needs of libraries; e.g., public relations, personnel administration, subject specialists, etc.

Assisting library training agencies not yet accredited

Organizing library clubs and fraternities

Issuing alumni newsletters

Impressing students with the necessity for recruiting

\section{On Library Staffs}

Raising salaries!!!

Improving working conditions in libraries Maintaining human relationships within library staffs (recognize merit; beware of seniority; relieve trained librarians of monotonous and clerical duties; give youngsters something besides routine jobs)

Providing in-service training for professional and subprofessional levels

Arranging summer training courses

Granting leaves of absence to subprofessional and clerical staff members so that they may attend library school

Providing graduate scholarships for promising students

Providing working-scholarships for undergraduates, and giving them the advantage of participating in various types of work

\section{Media of Publicity}

Bulletin boards, posters, billboards, exhibits, pamphlets, leaflets, newspaper columns dealing with books, magazine articles in professional and nonprofessional magazines, magazine article reprints, newspaper articles, articles in school papers, letters, speeches and informal talks, oral book reviews, radio programs and skits, radio spot announcements, films, film trailers, film strips, slides, charts, photographs, models, and cartoons. 